\title{
How the Not-So-Powerless Prevail: \\ Industrial Labor Market Demand and the \\ Contours of Militancy in Mid-Twentieth- \\ Century São Paulo, Brazil
}

John D. French

Historian Marco Aurélio Garcia began a discussion of working-class and leftwing parties in 2000 by asking, "Is a history of the left possible without a history of political militancy?" As a veteran Brazilian leftist, Garcia argued that an adequate analysis of a radical movement must explore the individual paths of militancy made visible through "autobiographical testimonies [that] allow the subjective dimension of historical processes to be reconstructed" in all its complexity. ${ }^{1}$ This examination of the social roots of militancy draws on 54 hours of interviews with Marcos Andreotti (I9IO-84), a lifelong Communist and trade union leader whose 60 years of political and labor militancy were spent in the ABC region of greater São Paulo (named for the three main municípios of Santo André, São Bernardo do Campo, and São Caetano do Sul). ${ }^{2}$ Andreotti was the

Special thanks are offered to Daniel James for our conversations over many years about Andreotti, to two excellent $H A H R$ reviewers of an earlier version of this manuscript, and to Alexandre Fortes, who provided decisive and useful guidance at a key point in the final revision of this article.

I. Marco Aurélio Garcia, "The Gender of Militancy: Notes on the Possibilities of a Different History of Political Action," in Gender and History: Retrospect and Prospect, ed. Leonore Davidoff, Keith McClelland, and Eleni Varikas (Oxford: Blackwell, 2000), 43-44, 50. A leader of the Brazilian and Latin American left since the 196os, Garcia is a longtime advisor to Luiz Inácio Lula da Silva and currently serves as Chefe da Assessoria Especial do Presidente da República Federativa do Brasil.

2. When I interviewed Andreotti in late 1982, the Brazilian Communist Party was still illegal, if haltingly tolerated, and the country was enjoying greater civil liberties as part of a tense and uncertain shift towards democratization. Our 54 hours of interviews over four months were carefully transcribed by Helena Weiss Gonçalves, to whom I owe a great debt of gratitude, with the final transcript consisting of 476 single-spaced pages. Unless otherwise noted, all interviews were conducted by the author in Santo André. Translations are the author's unless otherwise noted. 


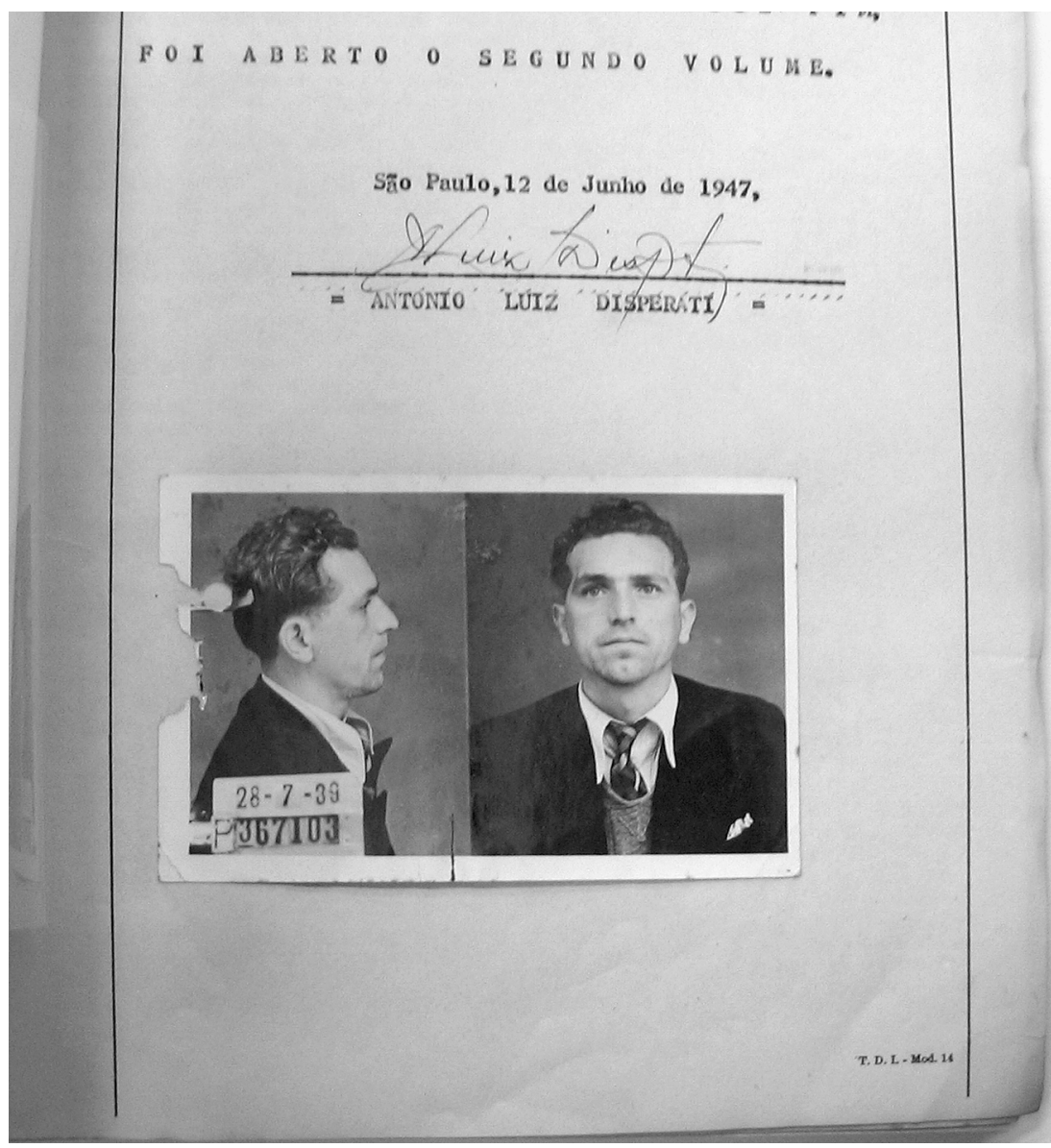

Figure 1. Photograph of Marcos Andreotti (1910-84), taken at his arrest in 1939, attached to the second volume of his prontuário with the Delegacia de Ordem Política e Social of the State of São Paulo, signed by the appropriate bureaucrat. Reproduced with permission from the Arquivo do Estado de São Paulo, DOPS dossiê 50-Z-318, pasta 7.

most important trade union leader in $\mathrm{ABC}$ prior to the emergence in the r970s of Luiz Inácio Lula da Silva, Brazil's current president. ${ }^{3}$

Methodologically, this article demonstrates the insights that can be achieved through a biographical approach focused on the phenomenon of militancy, an

3. For the only published piece on Andreotti, see Cândido Geraldez Vieitez, "Marcos Andreotti-Um gigante do primeiro movimento operário do ABC paulista," Novos Rumos 3, no. IO-I2 (I988): I53-76. 
arena "where the borders between the objective and subjective are weakened." 4 Biography's advantages are all the more important when the individual in question is effaced by dominant discourses. The human specificity of a Communist activist like Andreotti, for example, is denied by both the rhetoric of demonization from the right and by the grandiose and abstract language of official collectivist ideology on the left. Even in scholarly writing on labor and working-class politics, Communists are too often dealt with in terms of external labels rather than by interpreting these abstractions in light of the individual workers who made them a real force through their actions. When approached in this fashion, Garcia notes, concrete historical subjects are "engulfed by broad explanatory mechanisms," while individuals "appear as participants in an impersonal system." 5

Yet we will never truly understand labor history if we do not grasp the social and psychological dynamics that shaped individuals, like Andreotti, who stood at the center of organized working class and leftist struggle. Having joined the Communist Party at age I4, Andreotti served in the early I93Os as the first president of the $\mathrm{ABC}$ metalworkers' union. He later went underground and suffered two prolonged imprisonments. His 1947 election to the Santo André city council at the age of 37 confirmed his stature as a central public actor during the electoral and trade union successes experienced by the Brazilian Communist Party (PCB) during a brief postwar period of legality between I945 and I947.

This article focuses on the intensity of the Cold War repression after I947, which began under the elected presidency of Eurico Dutra, the former military strongman of the Estado Novo dictatorship (1937-45). Unrelenting police and employer persecution would profoundly disrupt the lives of ABC's Communists and their sympathizers, followers, and voters. ${ }^{6}$ Yet several dozen Communist militants did keep the "hammer and sickle" flying, although their running battle with employers, all varieties of police, judges, professional anti-Communists, and the state militia (Força Pública) exacted a fearsome toll on them and their families. This period of defeat, persecution, and organizational disarray will be

4. Garcia, "Gender of Militancy," 44. As Garcia (43) notes, these new approaches are linked to the best of the historiographical impact of second-wave feminism, which raised fundamental questions about the relationship between the public and private and the personal and political. See the introduction and conclusion of John D. French and Daniel James, The Gendered Worlds of Latin American Women Workers: From Housebold and Factory to the Union Hall and Ballot Box (Durham, NC: Duke Univ. Press, 1997), I-30, 297-313.

5. Garcia, "Gender of Militancy," 50.

6. For a recent general treatment, see Pedro Estevam da Rocha Pomar, A democracia intolerante: Dutra, Adhemar, e a Repressão ao Partido Comunista (I946-1950) (São Paulo: Arquivo do Estado de São Paulo / Imprensa Oficial do Estado, 2003). 
placed within the trajectory of Andreotti's working life as a skilled electrician. Placing his work experience front and center, the article argues that his position as a skilled worker provided the foundation for Andreotti's sustained militancy and his personal sense of himself as powerful. More importantly, it decisively shaped his philosophy of organizing on the factory shop floor, both as a Communist and a trade unionist.

Crucial methodological issues must be addressed if the retrospective oral testimony of a single individual is to be used to shed light on the larger phenomenon of radical political militancy and labor activism. We are long past the point where oral historical accounts and testimonios can be credibly viewed as the suppressed voices of subalterns, whose stories, from the bottom of unequal societies, represent transparent and ethically powerful counterhistories. It must also be emphasized that Andreotti is anything but a "typical" or representative worker. Andreotti's interviews do not constitute, in the words of oral historians Anthony Seldon and Joanna Pappworth, an "oral history of ordinary people: witnesses to, or receivers of, policy made by others." Given Andreotti's Communist politics, his sustained career as a leader, and his privileged location within the topography of the working class, the interviews are best seen as part of an "oral history of and about the 'élites' in society ... [that is,] those who rose to the top of their chosen occupation, and with whose activities much of modern scholarship, rightly or wrongly, is concerned-Cabinet ministers, trade union leaders, generals, chief executives, leaders of local government, novelists, and so on, rather than rank-and-file workers or soldiers."7

From the outset, my work with Andreotti was marked by a recognition that oral history is "not a new kind of history . . . but rather a type of source or evidence" that must be cross-checked, confirmed, or contested in light of both internal and external evidence. ${ }^{8}$ In the year before our first interview, I compiled documentary material from police, judicial, newspaper, and trade union sources on Andreotti's life and career. These sources served as the basis for detailed exchanges as we worked our way through the events depicted. The fruitfulness of this triangulation among written evidence, the interviewee, and the interviewer was only possible because Andreotti was an exceptional interviewee whose excellent memory, unusual degree of dispassionate self-awareness, and analytical bent made possible new insights into the interaction between political party militancy, factory organizing, and labor mobilization.

7. Anthony Seldon and Joanna Pappworth, By Word of Mouth: "Élite" Oral History (London: Methuen, I983), 6.

8. Ibid., 4 . 
Our interviews were characterized by a probing exchange in which I avoided excessive deference. In both the interview process and this article, I did not focus on the dissection of his style of storytelling or the dyadic nature of our relationship. Rather, I pursued a more ambitious objective: to understand Andreotti's leadership as an organizer. The immediate result of this collaboration is a unique exploration of how larger social and historical processes intersect with human subjectivity and political praxis. The oral history material in this article is combined with a unique body of documentary evidence that was not available at the time of the original interviews. The opening of the records of São Paulo's Delegacia de Ordem Política e Social (DOPS) provided an abundance of revealing new evidence dealing with specific events and individuals as well as general tendencies. This detailed contemporary evidence from a wellfinanced anti-Communist organ confirms the veracity of Andreotti's claims and places this Communist militant into a broader context that goes beyond what he was privy to as a participant.

The records generated by the police and informants of the DOPS highlight the obstacles that faced those, like Andreotti, who were uniquely vulnerable and apparently "weak" in the face of a specialized state organ of repression. At the same time, the failure to eradicate Communist militancy, despite the intensity of repression at the height of the Cold War, underlines the importance of understanding how Andreotti the militant, in a very real sense, "prevailed." Starting with the 1953 "strike of the 300,000," Andreotti played a key role in the rebirth of mass labor struggles and returned in 1958 as elected president of Santo André's metalworkers' union. During the reformist euphoria that followed, Andreotti oversaw the creation of the metalworkers' union of São Bernardo and Diadema, which Lula would head from I975 to I980, and was twice reelected president until his career as a trade union official was ended by the coup of I964. In tracing how objective conditions (labor market demand) shaped Andreotti's subjectivity and praxis, the article offers insight into unexpected continuities in the history of labor struggle between the era of Andreotti, before 1964, and the world of Lula's "New Unionism" beginning in the late I970s.

\section{Andreotti's Early Trajectory: Skill as a Foundation for Communist Militancy}

Although Andreotti was familiar with the classics of Marxism-Leninism, his Communism was never a solely theoretical or intellectual pursuit. Born to illiterate Italian immigrant parents, Andreotti did not complete primary school. Dialectical materialism, a term he knew, was less important to him than what he 
saw as the empirically validated insights offered by Marxism-Leninism for those who sought to successfully organize workers. In the PCB's internal division of tasks, Andreotti did not formulate general party policy; he claimed, perhaps correctly, to have never been a member of the local or state leadership. His special talent, recognized within the party and beyond, was in organizing the struggles of the working class at the point of production and in the trade unions. Since his teenage years, the practical work of organizing workers was his first love.

To attain this objective, Andreotti needed access to the workers, preferably through regular employment, since organizing from the outside, while possible, was infinitely less fruitful than direct contact with the problems of a given factory. ${ }^{9}$ Given the systematic blacklisting of troublemakers by employers and the DOPS and the public attention and eventual notoriety Andreotti acquired (not to mention the police record that followed), the biggest puzzle of his long career was how he managed to stay employed in industry. The answer can be found in Andreotti's occupation as a skilled industrial electrician. He had been lucky, in his first job at Santo André's Ipiranguinha textile plant in the midI920s, to have been assigned as an electricians' helper, which provided the initial training that led to his lifelong career. Like other skilled industrial occupations in midcentury São Paulo, the electricians' trade was not acquired by formal apprenticeships, vocational education, or employer training. ${ }^{10}$ Success depended upon years of practical learning from other skilled workers. To master the trade (profissão) required a high degree of personal initiative. Andreotti even used his time on the run from the police in the mid-I93os to improve his knowledge. An Italian-language book on the industrial applications of electricity was among the materials inventoried in the police record of a 1936 raid on his house, as reported in the 1939 legal proceeding against him in the Tribunal de Segurança Nacional (National Security Court). ${ }^{11}$

The special position of skilled workers in industrializing São Paulo profoundly shaped Andreotti's personal identity and his political militancy. The precipitous industrial expansion at midcentury occurred in a city without a significant body of skilled workers, whether immigrants or native born. Large-

9. For an example of factory organizing "from the outside," see the account of Andreotti's involvement with the agitation at the local Ipiranguinh textile factory in the late I93os. John D. French, The Brazilian Workers' ABC: Class Conflict and Alliances in Modern São Paulo (Chapel Hill: Univ. of North Carolina Press, I992), 71.

Io. Andreotti interviews, 20 Sept. and 2 Dec. I982.

II. Andreotti interview, 22 Oct. I982. Tribunal de Segurança Nacional, Arquivo Nacional, Delegacia de Polícia de São Bernardo, "Auto de Inquérito, Motivos de Ordem Social, I936," enclosed in Processo 705 (r939), 4:3r6-6r. 
scale government and/or employer programs to train such individuals were late in developing in Brazil. While employers had no problem acquiring the unskilled and semiskilled labor they needed, the machine technology of modern manufacturing required the services of specialized workers who were in short supply.

The scarcity of skilled industrial workers was an ongoing feature of the World War II era. ${ }^{12}$ Immediately after the war, São Paulo's industrial employers created the Serviço Nacional de Aprendizagem Industrial (SENAI), a factorylinked apprenticeship program that, although funded through a governmentmandated payroll tax, was directly administered by employers. ${ }^{13}$ Even this significant and sustained attempt to alleviate the shortage of skilled workers in São Paulo failed to definitely resolve the problem, due to the ever-accelerating pace of industrialization over the following decades. Numerous sociological studies of factories in São Paulo and ABC from the late I950s through the r970s attested to stiff employer competition for skilled workers. ${ }^{14}$

Indispensable to the running of the whole operation, skilled workers were thus prized by their employers and benefited from the competition for their services even when, as in Andreotti's case, they were politically "subversive." While Andreotti was unable to prevent employers from firing him, his skill, ingenuity, and persistence guaranteed that he was not unemployed for sustained periods. When fired by a metalworking firm for leading a strike in the early I930s, for example, Andreotti was soon hired by the then-bankrupt Ipiranguinha textile firm to maintain the plant's machinery in running order. Released from prison during the Estado Novo and under heavy surveillance, Andreotti still found jobs wiring houses and even did electrical installation work for the new Firestone plant being built in Santo André. In these cases, employers took advantage

I2. For references to wartime shortages of skilled workers, see French, Brazilian Workers' $A B C, 95$.

I3. Barbara Weinstein, "The Industrialists, the State, and Issues of Worker Training and Social Services in Brazil, I930-1950," HAHR 70, no. 3 (1990): 379-404; Barbara Weinstein, For Social Peace in Brazil: Industrialists and the Remaking of the Working Class in São Paulo, 1920-1964 (Chapel Hill: Univ. of North Carolina Press, I996).

I4. Juarez Rubens Brandão Lopes, "O ajustamento do trabalhador à indústria: Mobilidade social e motivação," in Mobilidade e trabalho: Um estudo na cidade de São Paulo, ed. Bertram Hutchinson (Rio de Janeiro: Ministério de Educação e Cultura, I960), 432; Luiz Pereira, "Qualificação técnica do trabalho," in Trabalho e desenvolvimento no Brasil, ed. Luiz Pereira (São Paulo: DIFEL, 1965), 252-53, 275; John Humphrey, Capitalist Control and Workers' Struggle in the Brazilian Auto Industry (Princeton, NJ: Princeton Univ. Press, 1982), 65, 100. 
of his skills without having to worry about his impact on the workforce. Yet employers' restrictions on hiring suspected subversives were loosened by the pressures of the industrial boom of World War II. At the time, he worked at the Matarazzo plant in Agua Branca in São Paulo but lived across the street from a textile plant in Santo André, whose owners would periodically ask him to fix some electrical problem. With the expansion of the plant's production, they hired Andreotti as a maintenance electrician. ${ }^{15}$

The owners of Santo André Textile, a small plant with fewer than a hundred workers, were keenly aware that the salaries and conditions of the booming textile industry were far from competitive. This was especially true compared to the region's many modern, heavily mechanized, and far more profitable metalworking, rubber, and chemical plants. Fully aware of Andreotti's past and current activities, the owners of Santo André Textile knew they would not have been able to afford Andreotti's services if he had not been politically suspect and unemployable in the better-paying, larger plants. Andreotti was more than willing to sacrifice part of the monetary return on his skill in order to sustain his political and union engagements. Thus, Andreotti's skills provided some protection from reprisals, despite his very public Communist militancy and his role as a rank-and-file opposition leader in the local textile union led by a rightist member of the Partido Trabalhista Brasilerio (Brazilian Labor Party, PTB). ${ }^{16}$

This profit-oriented bargain held through the November 1947 municipal elections, which were swept by the Communist candidates, almost all of them workers. Asked why the employers hadn't fired the 33 candidates, Andreotti noted that most were skilled workers, "except for Miguel Guillen, who had lost his job in industry and worked doing odd jobs [biscate]" like digging wells and construction. ${ }^{17}$ With the lack of skilled workers, the employers had to tolerate workers who had joined the newly legalized PCB if they were to meet their immediate demands of production. It was only in the aftermath of the November 1947 electoral sweep by local Communists that Andreotti's firm finally gave in to the concerted government-employer drive to uproot troublemakers from industry. ${ }^{18}$ Calling Andreotti into their office, the two owners said that his ser-

I5. Andreotti interviews, 20 Sept., 7 Oct., and 2 Dec. 1982.

I6. Ibid. Andreotti's employment as an electrician at the Fiação e Tecelagem Santo André in 1945 had been duly recorded in his personal prontuário, Acervo do Departamento Estadual de Ordem Política e Social, Arquivo do Estado de São Paulo (hereinafter cited as DOPS-AESP), dossiê 50-B-270, pasta I. On the disputes in the textile union, see French, Brazilian Workers' ABC, 175 .

17. Andreotti interview, 7 Oct. 1982.

18. Andreotti interview, 3 Nov. 1982. The full operation of this "employer-police alliance" during these years is explored in the first chapter of a scrupulously researched 
vices were no longer necessary since he refused to go along with the needs of industry. As Andreotti recalls the exchange, he responded aggressively since, as he told them, they needed his work to make their plant run. Irritated at his defiant demeanor, one of the exasperated owners could only restore the proper sense of hierarchy by opening a desk drawer to reveal a revolver inside. Shortly afterwards, in another reprisal, the same company fired one of Andreotti's daughters. This resulted in another confrontation when Andreotti angered her Italian foreman by calling him, in Italian, a doormat of the bosses. ${ }^{19}$

Andreotti's response should not be interpreted solely as a matter of individual temperament or Communist political ideology; rather, it revealed Andreotti's self-confident sense of his own indispensability to the employers, despite being a publicly known Communist. This sense of power was reinforced by another postwar experience when he was hired to work at Zapparoli Serena, a small chemical laboratory of 3 I workers that manufactured smelling salts. ${ }^{20}$ Andreotti valued this job because it allowed him to participate in the struggles against government-imposed intervenors in the chemical workers union. In this very public battle, the intervenors struck back by eliminating their rival Andreotti with the help of the management of the large local Rhodia Quimica plant. Since the raw materials for the laboratory were supplied by Rhodia, the laboratory's owner told Andreotti that he would have to lay him off. At the same time, however, the man was eager to keep his prized electrician and offered to keep paying Andreotti off the books. Andreotti refused, since his legal eligibility for union membership depended upon the entry in his working papers (carteira do trabalho). ${ }^{21}$

As we have seen, although industrialists agreed on the general policy of firing and blacklisting troublemakers, individual industrialists and managers often violated this policy when they desperately needed one or another skilled worker in order to make a profit on their enterprise. Indeed, for many small employers, the hiring of Andreotti not only filled an imperative need but did so at a bargain rate. Thus the comparative labor market advantage of skilled workers clearly

study of shop floor and trade union activism in ABC from 1945 to 1968; Antonio Luigi Negro, Linhas de montagem: O industrialismo nacional-desenvolvimentista e a sindicalização dos trabalhadores, $1945-1978$ (São Paulo: Editorial Boitempo, 2004), 2 I-78.

I9. Andreotti interview, 3 Nov. 1982.

20. Departamento Estadual de Estatística [do Estado de São Paulo], Catálogo das Indústrias do Estado de São Paulo (Exclusive o Município da Capital) 1945 (São Paulo: DEE, I947), 85 I.

2I. Andreotti interviews, 5 Nov. and 24 Nov. 1982. 
benefited Andreotti and distinguished him from the majority of the unskilled or semiskilled industrial workforce. Given their labor market leverage, skilled workers were also more likely to receive job tenure (estabilidade) than were the unskilled. ${ }^{22}$

\section{The Price of Communist Militancy at the Height of the Cold War}

During more than five hours of hard work, the 13 members of the nighttime municipal campaign caravan had painted multicolored slogans on sidewalks, streets, and walls throughout downtown Santo André. Reaching the gates of the enormous Pirelli complex at 2:30 a.m. on September I2, I95 I, the candidates and their supporters quickly daubed slogans in favor of the municipal nominees supported by the "Renovating Alliance for Peace and Against the High Cost of Living." Other graffiti demanded freedom for political prisoners and opposed the sending of Brazilian troops to fight in the Korean War. Alerted by the guard at the factory gate, the local police chief (delegado) led a contingent that, with loaded guns in hand, quickly surrounded and arrested the campaigners while confiscating their material and vehicles. ${ }^{23}$ Among those arrested was Marcos Andreotti, a candidate for vereador (city councilman), who had been described two years earlier in a DOPS report to the electoral court as a "longtime Communist militant" whose record of "subversive activities," including arrests and convictions, was already "so voluminous" that his file was "in its second volume."24 In its own internal records, the DOPS succinctly and accurately described Andreotti as one of the "most renowned elements in the party, active in agitation in the workers milieu." 25

Andreotti was taken directly to the DOPS headquarters in São Paulo; the police records reveal that he was the most aggressive of the $\mathrm{I} 3$ individuals interrogated. He began by declaring that he was a Communist and had been taken into police custody before for that reason. Yet he went on to protest that as a

22. Andreotti interview, 13 Dec. 1982.

23. Delegacia de Polícia de Santo André, "Auto de prisão flagrante," I2 Sept. I95 I, Tribunal Regional Eleitoral, São Paulo (hereinafter cited as TRE SP), Processo 348 (I96I); Andreotti interview, 17 Nov. 1982. For a DOPS account of the arrest at Pirelli, including a photo of the slogans, see DOPS-AESP, document no. 855, I4 Sept. I95I, dossiê 50-Z-3I8, pasta 7 .

24. DOPS, "Antecedentes Políticos Sociais de Antonio Moreira," TRE SP, Processo 348 (196I). The DOPS file on Andreotti referenced here can be consulted in DOPS-AESP, Prontuário No. 4980, 2 volumes.

25. DOPS-AESP, 24 Jan. I949, dossiê 5O-B-270, pasta I. 


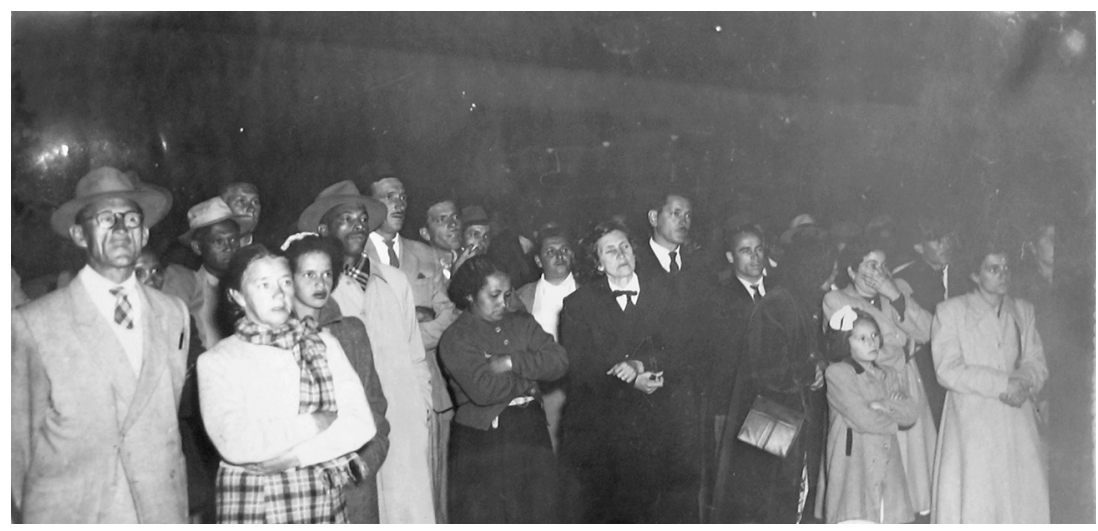

Figure 2. An interracial group of Santo André residents attend a September 8, 1951, campaign rally of the "Renovating Alliance for Peace and against the High Cost of Living" in favor of the candidacy of Dr. Antonio Refinetti and his Communist allies. Reproduced with permission from the Arquivo do Estado de São Paulo, DOPS dossiê 50-Z-318, pasta 7.

Brazilian citizen, although a Communist, he had the same right as anyone else to run for office. Asked in 1982 about what appeared to be a defiant demeanor, Andreotti insisted that his answers were simply a matter of

telling the truth. Nothing stopped me from doing so. I was well known to the police. ... As a [PCB] member and a union leader known ... [for] fighting for the workers' interests, I couldn't take any other attitude. To do otherwise would be to demoralize me vis-à-vis [desmoralizar perante] the people [povo] in general and even the party itself. So I tried to defend the rights of the people, of any individual, to be a candidate. I couldn't, in any fashion, [allow myself to] come out of this in a negative manner. ${ }^{26}$

26. Delegacia de Polícia de Santo André, "Auto de prisão flagrante"; Andreotti interview, I7 Nov. I982. Andreotti's open avowal of his affiliation in the $195 \mathrm{I}$ interrogations was not a matter of principle but rather a political judgment based on the circumstances. In I94I, by contrast, Andreotti "sought to defend himself with evasions" while being interrogated about Communist documents found in his house. As the police noted skeptically at the time, his claim "to have found that material beneath the door of his house" was a not very artful denial by an "an old aliançista militant [member of the radical Alianca Nacional Libertadora in the mid-I93os] and later communist." "Qualificação dos indiciados," 4 June I94I, DOPS-AESP, Prontuário de Policia 4980, vol. I. 
Andreotti's arrest came at a moment when the international Cold War had become a hot war in Korea. In Brazil, both the recently elected presidential administration of Getúlio Vargas and that of São Paulo's governor Lucas Nogueira Garcez (of the Partido Social Progressista of Adhemar de Barros) had only just begun to take shape. For the município of Santo André, the I95I municipal contest was the first since the dramatic Communist sweep of the I947 elections, which had been followed by the nullification (cassação) of the election of Communist candidates, including Andreotti. ${ }^{27}$ For local middle-class politicians such as medical doctor Antonio Refinetti, a candidate for mayor (prefeito) who was arrested along with Andreotti, electoral support by Communist voters was a potential trump card in the race for control of the municipal government of Santo André. ${ }^{28}$

As a member of the city council and president of the local Partido Social Democrático (PSD), Refinetti was the mayoral candidate of a political party that had, as a result of its conservative identification, won only minimal electoral support in working-class Santo André since 1945. Willing to go further in I95I than other stronger, local politicians, Refinetti had agreed to nominate a Communist as PSD candidate for vice-mayor (vice-prefeito) and to place nine others on the PSD city council slate in exchange for Communist votes for himself. By I95 I, such an alliance of convenience no longer seemed a matter of principle for the practical men of politics in São Paulo. ${ }^{29}$ It could, however, as in this case, lead to

27. For a full account of the Nov. 1947 Communist election victory in Santo André, see French, Brazilian Workers' ABC, 236-49; Ademir Medici, 9 de novembro de 1947: A vitória dos candidatos de prestes (Santo André: Fundo de Cultura do Município de Santo André, 1999). French offers a panoramic vision of the postwar upsurge in Santo André, and additional information can be found in Hélio da Costa, Em busca da memória: Comissão de fábrica, partido e sindicato no pós-guerra (São Paulo: Scritta, 1995), and a memoir by Armando Mazzo, the period's key Communist politician, Memórias de um militante politico e sindical no $A B C$ (São Bernardo do Campo: Secretaria de Educação, Cultura e Esportes da Prefeitura Municipal de São Bernardo do Campo, 199I). On the left and labor in ABC in the 195 os and early I96os, see Heloisa Helena Teixeira de Souza Martins, Igreja e Movimento Operário no ABC, $1954-1975$ (São Paulo: Editora Hucitec / São Caetano do Sul: Prefeitura Municipal de São Caetano do Sul, 1994); Cândido Geraldez Vieitez, Reforma nactional-democrática e contrareforma: A política do PCB no coração do ABC paulista, 1956-1964 (Santo André: Fundo de Cultura do Município de Santo André, I999), and Negro, Linhas de montagem.

28. Folha do Povo (São Paulo), 2r Aug. 195 I.

29. Andreotti interview, I7 Nov. 1982. There were some dissenters in the local PSD, as indicated by a statement from eight members of the party's Mauá diretório (directorate) that the local police chief passed on to the DOPS. DOPS-AESP, document no. 859, II Sept. I95I, dossiê 50-Z-318, pasta 7. Yet even the state PSD was not averse to this search for electoral advantage. "Defende o deputado Ulisses Guimarães o direito de registro dos candidatos apontados como comunistas," Folha da Manhã, 9 Oct. I951. 
inconvenience and embarrassment when Refinetti, convinced by his new allies, accompanied them on their nighttime graffiti-painting (pichação) expedition. ${ }^{30}$

After being held incommunicado for the first two days at the DOPS, the bulk of the group, minus Dr. Refinetti, spent the following eight days in the Avenida Tiradentes jail in downtown São Paulo, where Andreotti had served time during the Estado Novo. In keeping with the differential legal privileges accorded those who held university degrees (os doutores), the DOPS did not search Dr. Refinetti as they did the arrested workers, and he was released almost immediately. ${ }^{31}$ As Andreotti explained, "the title of doutor gives a right to a special prison [unlike] an electrician [who] is not a doutor. All intellectuals were kept in a special, more decent room even [when held in] the common prison [presídio comun]." In his judgment, this class "distinction was made in order to really create hate among people," although he did express a certain wry satisfaction that the doutor, despite his denials in custody, had in fact been painting graffiti like the rest of those detained.32

For Andreotti, his ten-day detention brought additional anguish because the police refused to release him to attend the wedding of one of his two daughters, despite public protests and a private promise by ex-governor Adhemar de Barros to arrange for his release. ${ }^{33}$ Yet this $195 \mathrm{I}$ arrest was not, in retrospect, a particularly serious matter since the charges were insignificant (only the pichação was illegal). As for the police, Andreotti observed, their behavior had not changed from the time of the Estado Novo. There were still threats, but the circumstances of his arrest were not "very propitious" for them to do anything stronger to him. The police had to content themselves with holding the candidates for ten days in order to disrupt their electoral campaign, while the legal case (processo) ended up being archived without a judgment (julgamento). ${ }^{34}$

30. Andreotti interview, I7 Nov. I982. The arrest exposed Refinetti to public attack, as in the mimeographed leaflet by a self-styled "National Resistance Alliance," which referred to "the well-known doctor Antonio Refinetti" as a "crypto-communist-a wolf dressed up as a lamb." DOPS-AESP, document no. 842, 7 Sept. I95 I, dossiê 50-Z-318, pasta 7 .

3I. "Even in twenty-first-century Brazil, the right of 'special prison' . . survives as an enduring legacy of the eighteenth century society of castes," having been broadened over time to cover a diverse array of groups. Linda Lewin, Surprise Heirs: Illegitimacy, Inheritance Rights, and Public Power in the Formation of Imperial Brazil, I822-1889 (Stanford, CA: Stanford Univ. Press, 2003), 2:60. Elected trade union leaders were legally accorded this honorific in 1955 , although it was never respected when people like Andreotti, a union president, were detained during the early ig6os.

32. Andreotti interview, I7 Nov. 1982.

33. Ibid.

34. Ibid. 
Andreotti was not surprised by his arrest, since police harassment of Communists or suspected Communists had become standard procedure over the previous three years. Indeed, the slogans of Andreotti's group included the call for the release of three local residents arrested in April 195I for trying to organize an anti-imperialist demonstration in Santo André. ${ }^{5}$ They also demanded freedom for the young Communist Eliza Branco, who had been arrested and sentenced to four years in prison for displaying an antiwar banner during the Brazilian independence day celebration of 1950 in downtown São Paulo. ${ }^{36}$

The atmosphere of unrestrained Cold War anti-Communism had also led, during the I950 election campaign, to a police clash that included the brutal beating of three "subversives" who were taken into custody after a campaign rally in São Bernardo do Campo, including former PCB state deputy Armando Mazzo, Santo André's prefeito cassado (mayor barred from taking office) in I947. This clash in Mazzo's hometown came on the heels of a court ruling against the registry of Communist candidates for federal deputy on the Partido Social Trabalhista (PST) slate in São Paulo. The court decision was followed by raids on PCB/PST election headquarters in ABC and elsewhere in which $\mathrm{I} 4 \mathrm{O}$ people were arrested, with most released shortly thereafter. At its height, the 1950 clash in São Bernardo involved the local police, the Highway Police, and specialized shock troops from the state militia who surrounded a truck carrying PCB/PST campaigners. Led by Mazzo, the badly outnumbered Communists refused to surrender and the three fought off the police with rocks, fists, wooden slats, and Molotov cocktails (which didn't explode); at least five civilians and four police were hurt. ${ }^{37}$ As a local policeman admitted to the author in 1982 , those detained were badly beaten with blackjacks. In justification, as Aureliano Monteiro pointed out, the Molotov cocktails indicated a disposition to fight, and fight they did. Mazzo reported that the local police chief told him, before the clash,

35. Ibid. In an article entitled "Enemies of the Country," a conservative newspaper in Santo André hailed the 8:00 p.m. arrest of Germano Canassa, Margarida and Ana Gimenez, and one other for trying to organize a picket against the inter-American military accord recently signed in Washington. Talking ominously of Moscow gold, the article said that Ana Gimenez was already being sought for a charge of attempted murder against a policeman from an earlier incident. Borda do Campo, 22 Apr. 1951. Along with Jorge Garcia, the three were convicted on 27 July I95I. DOPS-AESP, document no. 824, 27 July I95I, dossiê $50-Z-318$, pasta 7 .

36. On Eliza Branco, see DOPS, “Certidão," I3 Sept. I950, TRE SP, Processo I7d (I950); José Antonio Segatto et al., PCB: Memória fotográfica, I922-1982 (São Paulo: Brasiliense, I982), 98-99.

37. Folha da Manhã, 29 Sept. 1950. 
that "you Communists are bullheaded" (teimosos) for not leaving when given the chance (the delegado was a youthful acquaintance of Mazzo). ${ }^{38}$

Perhaps with the São Bernardo controversy in mind (Mazzo was reported dead in the newspapers), the minutes of the r95 I police interrogation of Andreotti and his comrades specifically recorded the Pirelli guard as noting that the police, while using "convincing means" in drawing their guns, had not beaten the arrestees or used any "manifest violence." 39 The presence of a 23-year-old civilian among those who arrested Andreotti and his comrades also reminds us that Cold War witch hunts thrived on the extensive use of police informants and professional anti-Communists, whether paid or unpaid. The role of one such informant, Milton Miguéis, in the official police documentation was to identify the individuals involved and to explain how the campaign graffiti fitted into the "world revolutionary program" laid down by Lenin. 40

The arrestees were well acquainted with Miguéis. Andreotti, even in I982, could not contain his feelings about this informer (dedo-duro, "hard finger") and immoral lowlife (safado), whom he identified as a police agent. A I95 I letter from the Santo André police chief confirmed that Miguéis had infiltrated Stalinist ranks and "even [been] arrested in the company of Communists," but had done so while "working for the police" (although not the DOPS, as Miguéis often claimed). ${ }^{41}$ The young man first came to prominence as an employee of the government-appointed junta in Santo André's metalworkers' union and was the author of numerous anti-Communist diatribes in the local press related to the 1950 union elections. ${ }^{42}$ His confrontations with the left took on a stark ideological coloration as well, given his public affiliation with the Partido de Representação Popular (PRP), an arguably "fascist" party founded by Plinio Salgado,

38. Interview by John D. French with Aureliano Monteiro, former delegado de polícia of São Bernardo do Campo, 6 Aug. 1982, in São Bernardo do Campo; see also Mazzo’s account in Memórias de um militante, $\mathrm{I} 25-26$.

39. Delegacia de Polícia de Santo André, "Auto de exibição e apreensão," I2 Oct. I95I, TRE SP, Processo 4I4/5 (I95I).

40. Ibid.

4I. This quote comes from a Sept. 195I letter to the DOPS by Santo André police chief Pio Buller, who explained that Miguéis, recorded ( fichado) as a Communist, had been unable to get a DOPS certificate (atestado) of his nonsubversive "political-social antecedents," a document required to run for office as well as in other official interactions. DOPS-AESP, document no. 858, I7 Sept. I95 I, dossiê 50-Z-318, pasta 7. In 1953, a DOPS report from Santo André noted that Miguéis, "an ex-functionary of the [metalworkers'] union," had "at various times [falsely] presented himself as a DOPS investigator."

DOPS-AESP, document no. 76, 3I Aug. I953, dossiê 50-A-247.

42. French, Brazilian Workers ABC, 235, 353 n. 4 o. 
the leader of Brazil's integralist movement in the I930s. ${ }^{43} \mathrm{~A}$ week before the I95I arrests, the local PCB urged its campaigners to attack the PRP as "a band of police agents" and "degenerates" (tarados); as for Miguéis, a PRP candidate, they said he "was known in Vila Assunção for the beating he received at the hands of the povo."44

The unrelenting police surveillance and ongoing repression of Communist campaigners in $195 \mathrm{I}$ did not ease up as the election approached. ${ }^{45}$ Four days before the vote, a group of I I PCB supporters were arrested. After confiscating their "clearly subversive propaganda," the local police noted their names for the files of the DOPS and then released them without charges. ${ }^{46}$ The routine nature of such procedures is suggested by the July I95 I detention of eight people in Santo André for distributing a leaflet with the slogan "Don't Pay the Fare [Não Pague Condução]." Their homes were subsequently raided and Communist literature confiscated. 47

Yet Andreotti could take some real satisfaction from the results of the October I4, I95I, municipal elections. Although the registry of his candidacy, and that of four of the PCB's other nominees on the PSD ticket, was overturned prior to the vote by the Tribunal Regional Eleitoral (TRE), the results indicated that Andreotti, along with Bruna Mazzo Fernandes (the sister of Armando Mazzo) and Alberto Zamignani, the former president of the local construction workers' union, would have been elected municipal councilmen in Santo André if the votes for the Communist candidates had been recognized. Coming in at the top of the PSD slate, Marcos Andreotti received more votes than seven of the non-Communist politicians who were eventually seated as members of the new 23-member municipal council. ${ }^{48}$

43. Bordo do Campo (Santo André), 27 Nov. I949; DOPS-AESP, document no. 827, 2I Aug. I95I, dossiê 50-Z-318, pasta 7.

44. DOPS-AESP, document no. 840, 7 Sept. I95I, dossiê 50-Z-318, pasta 7.

45. Two different DOPS investigators filed reports on each of the communist's campaigns rallies. DOPS-AESP, document no. 84I, Io Sept. I95I, dossiê 50-Z-3I8, pasta 7 .

46. Letter by Santo André police chief Pio Buller Souto to Dr. Manoel Ribeira da Cruz of the DOPS in São Paulo [195I], TRE SP, Processo 4I4/5 (I95I).

47. DOPS-AESP, document no. 815, 24 July I95I, dossiê 50-Z-318, pasta 7 .

48. For official results that omit the nullified votes received by the five excluded Communist candidates on the PSD slate, see "Suplemento" of the Boletim Eleitoral (TRE SP) 5, no. 8 (25 Oct. 195 I), in TRE SP, Serviço Informática, Caixa "Eleições de 195I." However, a local Santo André historian did report election results that include the votes for three of the five Communist candidates. While noting that these votes were null, he did not provide any explanation for what had ocurred. Octaviano A. Gaiarsa, A cidade que dormin três séculos: Santo André da borda do campo: Seus primórdios e sua evolução bistórica: $1553-1960$ 
Having been elected in 1947 but not seated, Andreotti knew in advance of the 195 I vote that he would never be allowed to serve in an elected capacity even if he were to once again triumph at the ballot box (he never ran for office again). Moreover, the Communists were at their postwar nadir in Santo André, having suffered an enormous decline during the intervening four years. In terms of overall electoral support, there was an 80 percent drop in votes for the Communist candidates running for the municipal council between 1947 and I95I. And the drop in PCB membership was substantial, in Andreotti's estimate: a decline from I, 000 prior to the outlawing of the PCB in May I947 to perhaps 600 by I95 I, using the loosest of definitions of "membership" to include virtually any form of sympathy or occasional support (his estimate gains some credibility from the minimum of 776 votes that Communists candidates received in I95I). 49

The Communist decline was most discouraging, however, in terms of organized and public participation in Communist activities. While perhaps soo to I50 Communists were identifiably active in early I947, fewer than 30 individuals were willing, like Andreotti, to brave the ostracism and persecution of the Cold War years. In fact, two-thirds of the 33 Communist candidates who ran for vereador in 1947 withdrew from the party, became inactive, or left the region..$^{50}$ While two dozen or so militants represented a net gain from early i945, when there were a dozen, this decline in party militancy severely restricted the ability of the Communists to effectively mobilize even their own supporters.

As a result, the dozens of PCB factory and neighborhood cells and local nonparty committees that had flourished between I945 and 1947 simply could not be sustained. Moreover, the trade union panorama was even more depressing for the local PCB in I95I. Not a single prominent Communist held union leadership, and blacklisted ex-leaders of the powerful left/center unions of the postwar period were reduced to the status of outside organizers, while their unions remained under the control of government-appointed intervenors. These intervenors had been confirmed in 1950 elections that were held without any competing slate due to labor ministry maneuvers. ${ }^{51}$

(Santo André: Prefeitura Municipal de Santo André, 1968), 228-29. For their unsuccessful appeal to the Tribunal Superior Eleitoral, consult TRE SP, Processo 348 (195 I).

49. Andreotti interviews, 28 Oct. and 24 Nov. 1982.

50 . Andreotti interview, 28 Oct. 1982.

5r. On the government's interventions in ABC's unions in 1947 and their sequel, see French, Brazilian Workers' ABC, 234-35, 25I; Andreotti interview, I8 Nov. 1982. 
"With the repressive action of the Police and the firing of communist workers in many [ABC] factories," noted an August I949 DOPS report, "a great gap emerged among the cadre of the local CP, leaving them ... in a tremendous crisis and with serious difficulties" in rearticulating themselves. As the DOPS noted with satisfaction, the latest round of imprisonments had led even more local workers "to distance themselves from party activities, whether out of fear of losing their jobs or of being jailed." 52 Andreotti's characterization of the situation in 1982 differed little from that of his antagonists: "it was a very awful period for the party" and "even the most active members found it difficult to join up with others.... The $[\mathrm{PCB}]$ cells in industry ... [were] undone by persecution within the factories ... . [and] those people [elementos] were scattered. Some went to São Bernardo, others to São Paulo, and in the end it was difficult to regroup . . . due to the persecution and secrecy" in which the PCB operated. ${ }^{53}$

In the face of this tight alliance between company and police, those militants who refused to back down threw themselves feverishly into the nationalist "Petroleum is Ours" campaign, circulated the Stockholm petition against nuclear weapons, and held countless rallies for peace and against the war in Korea, not to mention unending and futile protests against the ubiquity of government repression. ${ }^{54}$ On the labor front, public activism was marked by brief "lightning rallies," comícios-relámpagos as they were called, in which militants exhorted the workers at factory gates and then fled or, on occasion, confronted the arriving police squads.

All these PCB activities, including the party's electoral work, were fundamentally agitational in nature and involved dozens or, at best, hundreds and not thousands of workers. The PCB's struggle was reduced to a lonely battle of Communist militants against the police, leaving the popular majority as bystanders. This is exemplified by Mazzo's retrospective account of the I950 São Bernardo incident, which involved a large audience, including the "curious and those less understanding of what was going on." He wrote that, after beating off a first police attempt to dislodge them from the truck, "we waited for the popular reaction. Nothing. Just expectation. The mass without command either fires off without direction or stays perplexed. That's what happened: it stayed perplexed. The fight continued" with the Communists alone, badly bloodied, and in the hands of their enemies. ${ }^{55}$ Needless to say, this type of combative

52. The quote is from a document dated in Aug. I 949 to be found in DOPS-AESP, document no. II70, 2I Oct. I954, dossiê 50-Z-3I8, pasta Io.

53. Andreotti interview, 28 Oct. 1982.

54. Andreotti interviews, 17 Nov. and 27 Oct. 1982.

55. Mazzo, Memórias de um militante, 26. 
action, filled with anger and rage, came at an extremely high price to their members, and militants tended to burn out quickly. ${ }^{56}$ It was only in I954-55, as part of the shift away from the high Stalinist political line of the late I940s, that a national PCB leader advised local Communists in Santo André to avoid "street scuffles [arruaças]" so that "our best fighters don't fall into the hands of the police" or lose their jobs. ${ }^{57}$

The shift from a legally tolerated party with ro percent of the national vote in 1945 was abrupt and disorienting. After helping to draft the democratic constitution of 1946 , the PCB became the victim of a radicalization of repression that came to be mirrored, during this period of high Stalinism in the international Communist movement, by a voluntaristic and (on paper) even semiinsurrectionary political line (the "Manifesto of October" of I947). If what became known as the Populist Republic began with a democratic opening from I945 to I947, what followed was, in Andreotti's memory, a period of intense "reaction" that he characterized as a "phantom democracy [democracia fantasma]." ${ }^{8}$ When Andreotti was interviewed in 1982, Brazil was under military rule and his party was still illegal if haltingly tolerated. The country was enjoying greater civil liberties but only as part of a tense but uncertain shift toward democratization. During this period, the opponents of the regime often contrasted the military dictatorship to the civilian democratic republic of 1946 to I964. Although profoundly committed to the antidictatorial struggle, Andreotti could never idealize the period of I946-64 as simply "democracy"; he had seen and suffered too much for such a simplistic characterization.

\section{A Communist Electrician in a Democratizing Brazil:}

\section{The Dialectic between the Skilled and Unskilled}

On first reading Andreotti's I95I interrogation, I was surprised to learn that he had been employed at Indústria Sul Americana de Metais (ISAM), a newly opened metal laminating plant in Santo André with 500 workers. During our

56. As an example, one might take Joaquim Martes, in his mid-thirties, who was arrested in Oct. 1948 after leaving a meeting in Santo André, arrested again in Sept. 1950 when the PCB's electoral offices were raided, again in July I95 I when distributing leaflets, and yet again in January 1954 when he was condemned to two years in prison. DOPSAESP, document no. I098, I8 Mar. 1954, dossiê 50-Z-318, pasta 9. His I954 arrest and condemnation generated a swirl of publicity in the Communist newspaper Noticias de Hoje, 30 June, I6 July, II Aug., and 29 Aug. 1954.

57. DOPS-AESP, document no. i176, I6 Sept. 1954, dossiê 50-Z-318, pasta ıо.

58. Andreotti interview, 5 Nov. 1982. 
interviews, I was less surprised to learn from him about how he had been hired at ISAM but very surprised to learn why he had not, as I had expected, been fired after his ten-day detention. Andreotti originally learned about the job from a plumber friend who spoke to the firm's managers. Soon after being hired, his political affiliation came to the company's attention when they received an anonymous letter denouncing him as a Communist sent to disrupt the work of the factory. Asked about this by the manager who supervised his work, Andreotti admitted that he was a Communist but explained that this was a matter of his beliefs and would never interfere with fulfilling his responsibilities on the job. Judging Andreotti by his behavior and dedication to his work, the manager Dr. Jorge, an engineer, gave Andreotti a small raise, wrote on the bulletin board that any future denunciations should be made in person, and never spoke to Andreotti again about the matter. Even Andreotti's arrest and imprisonment as a "candidate of [Luis Carlos] Prestes" in I95I did not cost him his job; he had been allowed to take his vacation time specifically in order to campaign. 59

Clearly Dr. Jorge's response and that of his superior, chief manager Hercule Cavacini, a former engineer from Pirelli, were unusual and reflected the exercise of their discretionary powers as managers. In our interview, Andreotti also found this behavior exceptional and explained that the two men were not only "good bosses" but progressive and democratic in their thinking. It is not that they had any special sympathy for Communism, but their sense of fair play led them to reject the persecution of an individual for his ideas and not his deeds. As for Andreotti's imprisonment, they believed that everyone in a democracy had a right to be a candidate, whatever his ideas, without being interfered with by the police. 60

The response of ISAM's manager allows us to better understand the important but largely invisible underpinnings of mass belief that gave Brazil's imperfect democracy whatever real substance it had in I951. While the solemn rights and guarantees set forth in the I946 Brazilian constitution were being cynically violated by the state, the impact of these undemocratic actions could be somewhat altered when individuals, especially those in some position of power, actually believed in professed democratic ideals. In fact, this encounter, however fortuitous, provided Andreotti with his only period of relative employment stability: he would continue to work at ISAM, or on leave from ISAM as union president, until he was fired and then retired in I964-65.

While this may explain ISAM's refusal to arbitrarily fire him in I95I,

59. Andreotti interview, 3 Nov. 1982.

6o. Andreotti interviews, 3 Nov. and 18 Nov. 1982. 
Andreotti's long-term employment at the firm depended upon his proven skill as an electrician and his responsible attitude towards his work. Andreotti fell into the highest and best-paid of three classifications among ISAM's six or seven electricians, all male. As a fully formed professional, Andreotti was one of three electricians assigned to duty on each of three shifts (electricista de plantão). The high status of these elite electricians was based on their recognized competence and proven ability. Indeed, they were never asked to do installations or the other tasks assigned to the "general electricians," who were considered less "developed." 61

An electrician in Andreotti's position exercised a high degree of selfdetermination and control over his own activities within the plant. He passed his time in a small office connected by phone to the different sections and, if nothing was happening, he might stroll around the factory without questions being asked or even go and take a smoke at the factory gate. Moreover, he was never subject to the rough handling used by the supervisors of the unskilled and semiskilled workers of ISAM. ${ }^{62}$

Andreotti's work itself was varied and challenging. The electrician on duty had to be able to handle any and all electrical problems that might come up. In one such emergency, a worker's coat or fingers had gotten caught in the machinery and his arm was dragged upwards into the cylinder for cutting tin sheets. With his bloody arm destroyed and his body dangling above, Andreotti was called on to reverse the machinery in order to disentangle the man. On another occasion, he was sent to Paraná to mount a small factory that made domestic appliances. ${ }^{63}$

The fact that the quality of one's work directly reflected the mastery of the craft produced a strong sense of personal responsibility among skilled workers like Andreotti. Management valued him and kept him on, he explained, because "I was always a person who met his obligations" at work. Why, I asked him, shouldn't a worker protest his exploitation by being less diligent or hardworking? Admitting that some may have done this, Andreotti explained his philosophy in straightforward terms: "As a worker, I have rights and I have duties. I meet my duties in order to demand my rights." This invocation of the reciprocal

6r. Andreotti interviews, 3 Nov. and 2 Dec. 1982.

62. Ibid. Two studies of the paulista metalworking industry—one in the município of São Paulo in the late I950s and the other in São Bernardo in the early I970s-refer to the milder and less coercive treatment accorded skilled workers by management. Brandão Lopes, "O ajustamento do trabalhador à indústria," 430, 434; Humphrey, Capitalist Control, ror. 63. Andreotti interviews, 3 Nov. and 18 Nov. 1982. 
nature of workers' rights and duties vis-à-vis their employers reflected far more than simply Andreotti's personal philosophy; indeed, it constituted a fundamental part of his pedagogy of struggle and mobilization. ${ }^{64}$

Knowing full well the value of their labor, the skilled workers of midcentury São Paulo did stand up for their rights and make demands upon their employers. Even when unorganized, Andreotti recalls, the skilled were always more combative than the poorly paid manual laborer who most directly experienced, in his "own flesh, the exploitation that capitalism carries out against the worker." The skilled were also more likely to be union members ${ }^{65}$ and were disproportionately represented in the ranks of the Communist Party. ${ }^{66}$ The less-skilled workers, by contrast, "held more tightly to their jobs and left other questions aside." Aware of the flood of potential replacements outside the factory gate, the unskilled were acutely aware that their jobs required little or no training compared to an electrician, whose skills were learned, as Andreotti noted, in years, not months. "At the time there were few electricians and it was hard to find one at the factory gate asking for a job, unlike today." Their indispensability was also demonstrated by another story from ISAM. At one point, the plant's third eletricista de plantão was fired at the urging of a Bolivian engineer. Unable to get a satisfactory explanation for the firing, Andreotti got the man rehired when he told the head of personnel, "Well, you'll simply have to do his job tonight!" 67

The sense of power and personal efficacy enjoyed by the better-paid skilled minority was missing for unskilled or semiskilled workers. Lacking the buf-

64. Andreotti interviews, 3 Nov., I8 Nov., and Io Dec. 1982.

65. Andreotti interviews, 3 Nov. and 18 Nov. 1982. A 1963 study of the new WillysOverland auto plant in neighboring São Bernardo found that skilled workers were almost twice as likely to be union members as the unskilled. In addition, the skilled were far more likely to frequent the union headquarters. Leôncio Martins Rodrigues, Industrialização e atitudes operárias (estudo de um grupo de trabalhadores) (São Paulo: Brasiliense, 1970), 103-4. A 1970-71 study of an established medium-sized metalworking plant in Santo André also found higher union membership among skilled workers (42\%) than unskilled (29\%). Celso Frederico, Consciência operária no Brasil: Estudo com um grupo de trabalhadores (São Paulo: Ática, 1978$), 60$.

66. Andreotti interview, I8 Nov. I982. The vast overrepresentation of skilled workers in the Communist Party is strikingly clear among gold miners in Minas Gerais. In her study of Nova Lima, Yonne de Souza Grossi reports that 50\% of all local PCB members in I954 were plumbers (encanadores), an additional $45 \%$ were from other skilled sectors, and only $5 \%$ were from the ranks of the least skilled manual group, the carters (carreiros). Yonne de Souza Grossi, Mina de Morro Velho: A extração do homem: Uma bistória de experiência operária (Rio de Janeiro: Paz e Terra, 198I), I35.

67. Andreotti interview, 3 Nov. 1982. 
fer of skill, these workers were the most fully exposed to the risks attendant to their status as fully proletarianized wage earners. This stark contrast was imagined by some in Brazil in the early I960s to have clear behavioral implications, especially given the currency of terms like "labor aristocracy" that some intellectuals picked up from the books they were reading. In 1963 , for example, a small pamphlet entitled How Strikes Are Made in Brazil confidently posited that the "highly skilled" strata in industry — well-remunerated workers trusted by their employers — had an "almost nonexistent class consciousness." 68 The author, Jorge Miglioli, was an enthusiastic young Marxist intellectual, close to the PCB if not a member, who compared such workers unfavorably to the inferior strata of manual laborers receiving the minimum wage, who he described not only as more "class conscious" but more likely to strike and to do so with constancy and intensity. 69

The dialectic between the skilled minority and the less-skilled majority was indeed of fundamental importance to labor organizers like Andreotti, but the social dynamics in São Paulo were radically different from those imagined by Miglioli (as well as some later academic researchers). Shouldn't the well-paid and better-treated skilled worker, Andreotti was asked, be more loyal to his boss? He replied emphatically that it was precisely because the skilled worker "had a better salary and a better standard of living, [that] he wanted to get more ... and knew that he could get and conquer better conditions." Yet couldn't this lead to a go-it-alone policy or to the cultivation of elitist attitudes of superiority on the part of the skilled?70 Not for the most part, Andreotti replied, since the skilled worker was aware that he "earned so much [which was not enough], and that the poor fellow carrying material over there earned [even] less and could feed

68. Jorge Miglioli, Como são feitas as greves no Brasil? (Rio de Janeiro: Civilização Brasileira, 1963), 36-39.

69. Miglioli, Como são feitas as greves, $36-39$. Despite his solidarity with a labor movement increasingly characterized by Communist leadership, Miglioli's pamphlet is a particularly revealing case of "book learning" by those ignorant of labor struggles; virtually every generalization (including his description of strike participation) was empirically wrong. Associated with ISEB, Miglioli had published an article on "the critical role of the Marxist intellectual” in the PCB's national newspaper Novos Rumos, 20 Apr. I962 (\#163). For his retrospective characterization of the leftist intellectual ferment of the late 1950s, see Jorge Miglioli, “O ISEB e a Encruzilhada Nacional," in Intelectuais e Política no Brasil: A Experiência do ISEB, ed. Caio Navarro de Toledo (Rio de Janeiro: Editora Revan, 2005).

70. Andreotti interview, 3 Nov. 1982. In his 1957 study of a São Paulo metalworking plant, Brandão Lopes discusses the self-evident superiority that characterized the skilled who felt themselves "much above" the others. Brandão Lopes, "O ajustamento do trabalhador à indústria," 430, 434, 432. 
himself less well. [Considering all this] you never asked an improvement only for yourself but sought it in the general sense" for all. ${ }^{71}$

Yet this relationship was not entirely conflict-free, and when pressed, Andreotti admitted that some foremen did try to play upon the average workers' resentment at the higher pay and better conditions of the skilled. Yet "it was with great difficulty," he explained, "that the [unskilled] worker embarked in that canoe because one did a job of showing how the foremen squeezed" the common worker. This pressure for production stemmed, he would explain to them, from the fact that foremen received, in addition to their own salaries as supervisors, a percentage of their subordinates' production. Pointing this out, skilled workers like Andreotti argued that the foremen's percentage should go to those who actually did the work. Such arguments, he concluded, served as "a shock absorber" against these management maneuvers. Thus the alliance with the less skilled also fulfilled certain defensive needs for the skilled minority. ${ }^{72}$

\section{Worker Consciousness, Combativeness, and Forms of Struggle}

In summarizing his conclusions from a lifetime of shop floor organizing, Andreotti advanced a philosophy of mobilization that meshes nicely with his observations about the skilled and unskilled. Possessing enormous selfconfidence, Andreotti never used the either/or terminology of "class-conscious" or "non-class-conscious" workers, much less the term "false consciousness" occasionally used as shorthand by some Marxist intellectuals then and later. For him, all workers, even those who worked during a strike, had some level of consciousness (consciência) that could be raised through struggle around their felt grievances, however small or seemingly mundane, complaints he believed to be the natural and inevitable result of capitalist exploitation. ${ }^{73}$ Workers were not moved to action by simple denunciations of the boss or moralistic calls to struggle; in his judgment, the single biggest barrier to mobilizing workers lay in their inability to believe in their own power and capacity to change things they dislike.

This judgment served as the basis for the process of consciousness-raising and mobilization exemplified by Andreotti's experience at another local textile

7I. Andreotti interview, 3 Nov. 1982.

72. Andreotti interviews, 3 Nov. and 5 Nov. 1982.

73. On this point, see the discussion of individual grievances in John D. French, Drowning in Laws: Labor Law and Brazilian Political Culture (Chapel Hill: Univ. of North Carolina Press, 2004), II3-I5. 
factory in the late I940s. After losing his job at Santo André Textile, he found a position at a medium-sized firm of several hundred workers called the Justifício Maria Luiza, which manufactured products from jute. This specialized type of textile production was not particularly lucrative and paid low salaries for dirtier and harder work than in the cotton textile industry. As soon as Andreotti went to work there, he immediately noticed that the company was economizing at the expense of its employees through systematic noncompliance with existing labor laws. ${ }^{74}$

Refusing to pay any type of indemnification claims or overtime, the company ignored safety laws and even refused to pay the legally mandated wage increases set by textile collective agreements (dissídios coletivos) decided by the local labor courts. As he worked on machines and chatted with the workers, Andreotti found a generalized discontent that was most pronounced among the skilled. Most members of the workforce were women, and most were older workers with many years of employment at the plant. Familiar with this type of specialized work, even the skilled jute workers knew that their specific skills were not transferable to other types of textile production. Moreover, the overall decline of the jute industry meant that they did not benefit from competition among rival employers. ${ }^{75}$

In setting things in motion, Andreotti focused on the violation of the labor laws. ${ }^{76}$ While the responsibility for monitoring and enforcing the laws lay with the government, the Labor Ministry's inspectors "lived more from the employer's pocket book than from their own salaries," Andreotti said. Inspectors ignored evidence of company violations, and their superiors had few incentives to control such collusion due to the Dutra administration's pro-employer policies. ${ }^{77}$ Ideally, the local textile union should have policed the inspection process or instituted legal cases in the labor courts over such violations. Yet past efforts by the company's workers to convince the union president Henrique Poletto to act had come to naught. Identified with the dominant accomodationist (peleguista) current of local unionism, Poletto was close to the plant's owner Trevisolli, according to Andreotti. ${ }^{78}$

74. Andreotti interview, 24 Nov. 1982.

75. Ibid.

76. On "legal agitations" and how the labor law shaped both the legal consciousness of workers and their "characteristic forms of social critique, protest, and mobilization," see French, Drowning in Laws, 97-98, 7.

77. Andreotti interview, 24 Nov. 1982. For more on corruption in the labor inspections carried out by the government, see French, Drowning in Laws, 74 .

78. Andreotti interview, 24 Nov. 1982. 
Disgusted with the government and the union, the workers had resigned themselves to endure their conditions. Serving as a catalyst, Andreotti set out to prove that they themselves had the power to alter the situation and force the union and the government to act. Over his year's employment there, he brought together a group of workers, women and men in equal numbers, willing to try and do something about conditions. Meeting in homes and chatting on the shop floor, they resolved to circulate a petition detailing the abuses at the plant, which was to be presented to the union by Andreotti. ${ }^{79}$

The scene at union headquarters was captured by a local newspaperman who encountered a crowd of Maria Luiza workers milling around the textile union headquarters. Faced with demands that the union act upon their grievances against the company, the harried union president Poletto responded that he would take the necessary steps to prevent such extortion in the future. In the end, as Andreotti always put it, "we achieved something," including overtime pay and greater respect for some labor laws, even though not all the workers' demands were met. ${ }^{80}$

Andreotti had been hired at the Justifício Maria Luiza without knowledge of his politics, and the owner Trevisolli had watched his activities with anger. Informed by Andreotti's union opponents of his past as a "terrible Communist," Trevisolli fired the "agitator" in the immediate aftermath of the mobilization at the union. Yet the fact that the owner fired only Andreotti also taught the workers a lesson of importance. Their employer obviously faced some of the same labor market constraints as his workers since he could not easily find replacements for his now rebellious employees who stayed on the job.

Even the firing of Andreotti did not, in the end, achieve its purpose of discouraging the plant's workers. Told of his firing, Andreotti insisted on going into the factory to settle what he said was some pressing business affairs. Once inside, Andreotti explained what had happened and began to agitate the question among the workers. With one year's employment at the plant, Andreotti was eligible under the job tenure laws for an indemnification of one month's pay. Most of the workers, however, did not believe Andreotti's claim that the owner would pay. When Andreotti, following further heated discussion with the owner, finally won the argument, he returned to the shop floor to show the workers the money he was paid by Trevisolli, who by then was eager to end the whole affair before something more dramatic happened. Through unity and struggle, the workers learned, even a notorious agitator could beat the bosses. In

79. Ibid.

8o. Ibid.; Folha do Povo, io Mar. 1950. 
the aftermath, an important psychological barrier had fallen among the plant's workers. No longer convinced that nothing could be changed, a group of the plant's workers went on to become an important and vocal part of the local union, first in opposition to Poletto, and then in collaboration with his centerleft successor Geraldo Milani in $195^{2.81}$

Yet the successful mobilization of workers around their immediate demands did not, in and of itself, advance Andreotti's wider political objectives. As a Communist, Andreotti was convinced that the workers' economic and political struggles were inseparable and could only be fully realized through a revolutionary change in regime. Yet he knew that these views were not shared by the majority of workers preoccupied with their own immediate problems. ${ }^{82}$ In discussing workers' consciousness, Andreotti always distinguished between workingclass "combativeness" directed against immediate economic grievances and workplace conditions and a broader and less common political consciousness. While working-class combativeness varied among individuals and groups, it was always more common than a political awareness of the workers' struggle beyond the factory to demand gains from or changes in the government. ${ }^{83}$

The class struggle had its greatest transparency on the job, where shared economic and workplace grievances made it possible to sustain a unity of purpose among the workers that did not necessarily exist outside the factory gate. In this sense, the workplace and the trade unions were the fundamental arena of class struggle. Once workers were set in motion around their economic demands, Andreotti believed, they could then arrive at broader political conclusions. As he pointed out with pride, the economic struggle at the Justifício Maria Luiza produced not only a mobilized workforce but the formation of a Communist cell that lasted until the closing of the plant the following decade. ${ }^{84}$

Andreotti saw the class struggle, in other words, as an educational process of consciousness-raising (conscientização) through which workers gained an increasing sense of power as they moved from smaller to larger and more sweep-

8I. Ibid. The active participation of Justífico Maria Luiza workers in the local textile workers union after Andreotti's departure is documented in DOPS-AESP, document no. 904, 5 February I952, dossiê 50-Z-318, pasta 8; document no. I000, 25 Mar. I953, dossiê 50-Z-318, pasta 9 .

82. Andreotti interview, 7 Dec. I982.

83. Andreotti interviews, 18 Nov. and 27 Nov. 1982.

84. Andreotti interview, 24 Nov. 1982. The existence of a PCB cell among Justifíco Maria Luiza workers, as claimed by Andreotti, is confirmed in DOPS-AESP, document

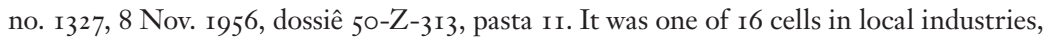
including ISAM, where Andreotti was employed. 
ing objectives. Yet, doesn't an emphasis on winning modest workplace or community improvements, I asked Andreotti, produce accommodation and reformism? Wouldn't small victories within the capitalist system serve as a disincentive to struggle by satisfying the workers' demands? "To march towards revolution," Andreotti replied, "it is necessary to raise the people's awareness of their own force ... and show them how to win economic and political improvements." 85

That forward march, Andreotti insisted, should never be discounted as reformism, because "if the people are not conscious [consciente], not convinced of their own force, they will never make a revolution" (or anything else for that matter). And each time a victory is gained, however small, workers learn that "dispersed they won't gain anything" and become convinced that "united they can win." This growing self-confidence would in turn make it easier to organize workers for more ambitious struggles, even socialist revolution. ${ }^{86}$ Socialism, he went on, depended upon the ongoing development of workers' consciousness both during and after victory. ${ }^{87}$ Drawing an example from the Italian factory occupations of the early I920s, he observed that the workers simply abandoned the factories they were running once the raw materials were exhausted; thus the revolution failed to consolidate itself. And after socialism was established, it would still require the ongoing political education of workers so that socialism could advance and provide better laws for the worker. ${ }^{88}$

\section{The Meaning of Communist Militancy on the Shop Floor}

What then was the relationship between an individual's Communist militancy and his role in the shop? Like any worker, Andreotti argued, it was a Communist's obligation to build their trade union, and he believed that a fully formed class politics gave them a special ability to lead the workers' economic struggles. Imbued with a sense of personal responsibility for his class, the militant's goal was to inspire his fellow workers to struggle through his personal example of self-sacrifice. As an example, Andreotti told the story of a Communist worker,

85. Andreotti interview, 3 Nov. 1982.

86. Ibid. Emphasis added.

87. Andreotti interview, 18 Nov. 1982.

88. Andreotti interviews, 3 Nov. and I $_{5}$ Dec. 1982 . The leadership role of skilled workers in labor and radical movements has parallels beyond Latin America. For a brief discussion that places this case into a broader international comparative dialogue with early twentieth-century developments in metalworkers' industries in the North Atlantic, see John D. French, "The Latin American Labor Studies Boom," International Review of Social History (Amsterdam) 45, no. 2 (2000): 294-97. 
newly hired as a guard at Pirelli, who was asked by his supervisor, two days after being hired, to attend a union meeting and report back on what was said. Despite needing the job to support his family, the man not only refused but publicly disclosed the request to a union meeting the following day and was immediately fired. 89

Generalized moral precepts about duty and self-sacrifice do not, however, tell us much about the actual operation of the Communist Party in industry, a subject that was for too long shrouded in secrecy by its participants and obscured by employer and government propaganda about Communist infiltrators and agitators. ${ }^{90}$ Exaggerated by some and romanticized by others, an examination of the Communists at ISAM reveals a more modest but still vital role. When Andreotti entered the factory, he found a natural nucleus of party organization among five recent recruits to the Communist Party, among them three skilled workers. Ranging in age from their twenties to late thirties, these men were combative workers who, aware they were being exploited, "wanted to fight but didn't know where to start." Since they were "politically weak in terms of understanding party policy," Andreotti concluded that they were best worked with in a "union way [sindicalmente]" by focusing the cells' activities on workplace grievances and economic demands..$^{91}$

This distinction between trade union work (trabalho sindical) and political party work was of fundamental importance to Andreotti's praxis. The trade union, Andreotti repeatedly emphasized, could not be political in a party sense since it represented the largest unity of the workers around their broadest shared grievances. His own shop organizing, by the same definition, was trade union work and not specifically Communist activity. In this scheme, only his

89. Andreotti interviews, 5 Nov. and I6 Dec. 1982.

90. Negro, Linhas de montagem, provides the most detailed exploration to date of Communist activism in ABC's metalworking industry and unions from 1945 to 1968 , through extensive use of DOPS records and other sources. (My Andreotti interviews were not available to Negro.) For a fuller evaluation of this pathbreaking monograph, see my review in Labor: Studies in Working Class History of the Americas (forthcoming, 2009) and the longer review essay that analyzes its place within the broader historiography on ABC's metalworkers: John D. French, 'Lula, the 'New Unionism,' and the Brazilian Workers' Party: How Workers Came to Change the World, or at Least Brazil," Latin American Politics and Society 54 (November 2009).

9r. Andreotti interviews, 5 Nov. and 18 Nov. 1982. As per Andreotti's description, the 1954 DOPS report on ISAM's PCB cell listed seven workers by name, only one of them identified as a common worker (the occupations of the other six were listed as electricista, mecânico, mestre laminador de cobre, trafilador, and refilador). DOPS-AESP, document no. II70, 2I Oct. 1954, dossiê 50-Z-318, pasta Io. 
discussions with fellow workers about politics or his distribution of the party newspaper and literature to sympathizers counted as specifically political work.

Leadership of the plant's Communists fell naturally to the veteran Andreotti, who began by establishing a functioning party organization. Meetings were normally scheduled every Io to 20 days at members' homes, although conflicts in work schedules often led to a month passing between meetings. ${ }^{92}$ Cell discussions were designed to arrive at specific tasks that each member could undertake. Because new members were fearful of appearing publicly, they were given less exposed tasks such as placing small leaflets on the machines in the plant or simply sounding out their acquaintances. Until these individuals gained confidence, the task of directing the party's word to the workers fell to Andreotti as the most experienced member. Moreover, his job as an electrician did not tie him "to the foot of the machine." Thus Andreotti was able to circulate freely throughout the plant chatting with the workers of different sections and getting to know their problems. ${ }^{93}$

Over his decades of militancy in the labor movement, Andreotti had learned that patience and persistence were the key to long-term success. Any fears among workers who knew, or might learn about, his Communist beliefs could be overcome by establishing that he authentically cared about their problems and could offer them real and practical solutions. In that context, Andreotti could also gain their admiration and respect as an individual who had the guts to stick up for them and do what they themselves were afraid to do (which was easier for those with labor market leverage). Over time, Andreotti, his comrades, and the core of union members they were building gradually gained an accepted position among the plant's workers. ${ }^{94}$ Raising and resolving the small problems that affected individuals or groups of workers, they preached a gospel of strength through unionism that won an increasing number of adherents for the union leading up to 1964 .

The work of Andreotti and ISAM's PCB cell was also based on a pragmatic understanding that the outlook and degree of combativeness of the workers set strict limits as to what the radical minority could achieve at any given moment. In the early I950s, the workers of ISAM were angry but resigned to the existing state of affairs, as were most workers in São Paulo, and recent experience had left them

92. Andreotti interviews, 5 Nov. and 18 Nov. 1982.

93. Andreotti interview, I8 Nov. 1982. For a Chilean example of how on-the-job contact afforded by the electrician's job could figure in shop floor organizing, see Peter Winn, Weavers of Revolution: The Yarur Workers and Chile's Road to Socialism (Oxford: Oxford Univ. Press, 1986), 24, 93-94.

94. The cell eventually grew to ten members. Andreotti interview, I8 Nov. 1982. 
rightly skeptical about their prospects of winning anything. If victories, however small, are required to encourage mobilization, as Andreotti believed, then defeats can be expected to produce this sort of retreat from struggle among workers.

Moreover, the new ISAM workforce did not have a history of mobilization and established internal leadership as did the metalworkers of the local Pirelli factory. This collective history had to be created from scratch. As Andreotti knew very well, workers could not be convinced to move directly from passive inactivity and generalized grumbling directly to a radical action like a strike. Under these conditions, ISAM's Communists did not directly advocate strikes but rather set about the long-range process of education and consciousnessraising. The role of the Communists in this process was to act as a catalyst for action about issues of concern to workers. "The importance of [party] organization," however small, Andreotti argued, was "that together you can discuss and carry out tasks.... In a factory where the laws are being violated [for example], these four or five people can meet to think about how to make the workers understand the need to organize to win enforcement of the laws." While "a person alone can never achieve anything," this small group can "bring this minimum demand to the knowledge of the others" so that, once convinced of the need, they could be mobilized to win some sort of victory. ${ }^{95}$

\section{Conclusion}

Drawing on divergent sources, this article has used Andreotti's life story, as seen through his own eyes and narrated in his own words, to shed crucial light on the poorly understood foundations of working-class political and labor militancy in mid-twentieth-century Brazil. While paying focused attention to the height of the Cold War, this episode was placed into the broader trajectory of Andreotti's working life. Leftist militants, as Marco Aurélio Garcia reminded us in 2000, may " "apply' the party 'line' in society" in many ways, including "a speech, pamphlet, other methods of 'agitprop' or violent armed action." Yet how they do so is profoundly influenced by the fact that they "are specific people, men and women, bearers of ethical values, political convictions and religious influences" derived from their familial, educational, and cultural backgrounds. In tracing the genesis of the sense of personal power that undergirded Andreotti's militancy, this article suggests that an individual's labor market insertion may have an equally profound impact. ${ }^{96}$ 
The central paradox lies in the fact that Andreotti, despite the victimization to which he was systematically subjected, did not personally feel himself to be powerless. Andreotti did not see himself as a victim, nor was he primarily an object of action, repressive or otherwise, by the powerful. Rather, Andreotti's class, trade union, and Communist identity turned out to be inseparable from a deeply held sense of personal power. His ability to prevail, in a satisfying psychological sense, was firmly linked not to his Marxist-Leninist ideology — although its importance should not be denied — but to his structural placement as a skilled worker. And this sense of individual power, it is revealed, becomes intertwined in surprising and unexpected ways with the process of building working-class collective power. As the article suggests, Andreotti's remarkably coherent philosophy of organizing derives in good part from the lessons he drew from what I have called the dialectic between the skilled and the unskilled within the industrial proletariat.

Over his six decades of political militancy, Andreotti spent time as a clandestine revolutionary, went to prison for several years, won enough votes on two occasions to become Santo André city councilman, and was elected union president four times. In I960, he oversaw the creation of a new metalworkers' union in São Bernardo do Campo and Diadema that would become the heart of the metalworkers' strikes that swept the entire ABC region between 1978 and I980. In addition to suffering countless job losses, Andreotti faced routine police harassment, arrests, and detentions; indeed, the last police raid on his house was in 1978 , the year of the first strikes in São Bernardo that brought national attention to a 33-year-old trade union leader named Lula. A year before my interviews with Andreotti, a DOPS agent filed a November 28, I980, report about his encounter with José Ferreira de Melo (Frei Chico), Lula's older brother and a member of the PCB, during a meeting of the Opposição Sindical in São Caetano do Sul.97

In the I970s and I980s, intra-left disputes necessarily pitted the old(er) Communist-associated leftists against the groups that joined the Workers' Party founded in I980 by Lula. With more distance, Brazilian labor history scholarship has come to recognize a substantial degree of continuity across

97. DOPS-AESP, document n.n., 28 Nov. I980, 50-B-270 I- Io9, pasta I. As happened to many leftist militants, Frei Chico was detained and tortured ferociously in I975, after he had been elected vice president of the metalworkers' union of São Caetano. (Lula was elected president in neighboring São Bernardo the same year.) For his detailed and moving account, see Denise Paraná, Lula, o filho do Brasil, rev. ed. (São Paulo: Editora Perseu Abramo, I993), I77-89. 
regime types and political affiliations over these crucial decades. ${ }^{98}$ A promising line of new research is suggested by this article's focus on the leading role of the skilled, which includes Lula, who was trained by the employer-created SENAI agency in the I96os. In I974-75, English sociologist John Humphrey studied the Ford plants in ABC and São Paulo for a dissertation completed a year before São Bernardo first became famous. As he admitted in his excellent 1982 book on São Bernardo's metalworkers: "The major error in my [earlier I977] analysis was to fail to perceive the importance of skilled workers" and to assume they would stand apart from the struggle. ${ }^{99}$ And the sentiment of a São Bernardo toolmaker, in discussing the 1978 strikes, directly echoes his older companheiro Andreotti's retrospective reflections: "We fight for the others and we even understand why it takes time for them to join us."100

My brief examination of Andreotti's biography also provides dramatic proof that the Brazilian political system before I964 failed to meet minimal definitions of democracy, whether in terms of equality before the law, respect for freedoms of association and expression, or acceptance of the ballot box as the sole means of determining the popular will. ${ }^{101}$ The 2002 election of a former metalworker as Brazil's president provides dramatic evidence of the profound changes that have occurred since then. ${ }^{102}$ Two years before my interviews with Andreotti, an epic I980 ABC metalworkers' strike led by Lula went down to defeat with police beatings in the streets of São Bernardo, arrests of militants and union leaders (including Lula), and government intervention in ABC's metalworkers' unions. Thus, it is not surprising that Lula's victory speech would directly invoke the past he shared with Andreotti and so many others like him:

Our arrival at the Presidency of the Republic is the fruit of a vast collective effort realized across decades by innumerable democrats and social fighters. Many of them, unfortunately, did not live to see Brazilian

98. For an excellent review of a group of recent monographs, see David McCreery, "Gift of the Devil," Social History 33, no. I (2006): 68-77.

99. Humphrey, Capitalist Control, I I9, I49.

Ioo. Ibid., I62.

Ior. On the ubiquity of repression and its impact on workers' consciousness, see "The Politics of Aphorism: The Social Question as a Police Matter (Caso de Polícia)," in French, Drowning in Laws, I22-50. The broader significance of this criminalization of social struggle is emphasized in John D. French and Alexandre Fortes, "Another World Is Possible: The Rise of the Brazilian Workers' Party and the Prospects for Lula's Government," Labor: Studies in Working Class History of the Americas 2, no. 3 (2005): I6. I02. See my forthcoming book entitled Lula's Politics of Cunning: From Trade Unionism to the Brazilian Presidency. 
society, and especially the oppressed sectors, reap the fruits of their arduous labor, their dedication, and their militant sacrifices. Wherever they are, the companheiros and companheiras that death took before this moment should know that we are the inheritors of their legacy of human dignity, personal integrity, love of Brazil, and passion for justice. 103

With enough distance, the time has now arrived when historians should take seriously the judgment offered by two young sociologists who had applied a questionnaire to the São Paulo and Rio delegates to the Second National Congress of Metalworkers held in April 1959 in Itanhem (attended by union president Andreotti). The proletariat in Brazil's industrial heartland, they wrote in I962, was emerging as a group whose "social, political and economic influence . . . has been increasing rapidly and whose participation in decision making - that is, its 'power' - has tended to broaden." Within this general panorama, they judged that "the metalworkers' union leadership represents, perhaps better than any other group, the new tendencies" at work in the Brazilian labor movement before $1964 \cdot{ }^{104}$

I03. Luiz Inácio da Silva, "Compromisso com a mudança: Pronunciamento do presidente eleito Luiz Inácio Lula da Silva em 28/10/2002” (2002), Fundaçao Perseu Abramo, http://www2.fpa.org.br/portal/modules/news/article.php?storyid=2317 (accessed 20 July 2009). My translation.

I04. Michael Lowy and Sarah Chucid, "Opinões e atitudes de líderes sindicais metalúrgicos," Revista brasileira de estudos políticos I3 (I962): I33, I4I. This 1959 metalworkers' congress was attended by Andreotti. 